\title{
Omissions in the synthetic theory of evolution
}

\author{
Daniel Frías L.
}

Instituto de Entomología, Universidad Metropolitana de Ciencias de la Educación, Código Postal 7760197, Santiago. Chile, E-mail: daniel.frias@umce.cl

\begin{abstract}
The Synthetic Theory of Evolution is the most unifying theory of life science. This theory has dominated scientific thought in explaining the mechanisms involved in speciation. However, there are some omissions that have delayed the understanding of some aspects of the mechanisms of organic evolution, principally: 1) the bridge between somatic and germinal cells, especially in some phylum of invertebrates and vertebrates; 2) horizontal genetic transferences and the importance of viruses in host adaptation and evolution; 3) the role of non-coding DNA and non-transcriptional genes; 4) homeotic evolution and the limitations of gradual evolution; and 5) excessive emphasis on extrinsic barriers to animal speciation.

This paper reviews each of these topics in an effort to contribute to a better comprehension of organic evolution. Molecular findings suggest the need for a new evolutionary synthesis.
\end{abstract}

Key terms: Evolution, non-transcriptional genes, viruses, homeosis, epigenesis, imprinting, neo-Lamarckism, sympatric speciation.

\section{INTRODUCTION}

The synthetic theory of evolution is considered the most unifying theory of life science. This theory is mainly based on neo-Darwinism, particularly on Mendelism, population genetics, mutations, natural selection, gradualism, and the central dogma of molecular biology. These are key topics to explain genome changes, speciation phenomena, and biodiversity.

Neo-Darwinism roots are found in August Weissmann's theory of continuity of the germplasm. Weismann established that organisms have two sets of cells: somatoplasm and germplasm. In the latter, there are particles or biospheres associated with chromosomes responsible for the transmission of inherited characters. Thus, Weismann laid the foundations of chromosome theory of inheritance. He rejected Lamarck's theory of acquired characteristics, and challenged all these ideas of the natural selection theory of Charles Darwin. Thus, Neo-Darwinism emerged, by adding Weismann's theory of the continuity of germplasm (East, 1929; Darlington, 1937).

The rediscovery of the principles of Mendel by Hugo de Vries, Carl Correns and Erich Von Tschermak strengthened Neo-Darwinism, and with the contributions of Fisher, Wright, Haldane, Dobzhasky, Mayr, Simpson, Stebbins and Huxley, "Population Genetics" and "The Synthetic Theory of Evolution" emerged. Since its origins, this theory has dominated the minds and thoughts of scientists in explaining the mechanisms involved in the phenomenon of speciation. However, important omissions have prevented a full understanding of the processes involved in organic evolution. Especially, there is little consideration regarding: 1) the lack of a bridge between somatic and germinal eukaryote cells, 2) lateral genetic transferences performed by plasmids and viruses in the genome of eukaryotes, 3) the lack of a holistic concept of the gene, determinism, and genetic reductionism, 4) non-coding DNA, 5) epigenesis, 6) homeotic mutations and the genetics of development, and 7) sympatric speciation.
The goal of this article is to discuss these topics to contribute to a better understanding of the mechanisms involved in organic evolution.

The absence of a bridge between somatic and germinal cells in some phylum of invertebrates and the heredity of somatoclonal variation

One of the assumptions of population genetics is that genes are vertically transmitted to the progeny according to the laws of Mendelian inheritance. In this context, and based on Weissmann's barriers between somatic and germinal cells, only genetic changes that take place within gametes are inherited by the next generation. Nevertheless, in many invertebrate organisms there are no barriers between somatic and germinal cells. For example, in the phylum porifera (sea sponges) and coelenterata (medusa) there are no differentiated germinal lines. Sexual sponge cells originate from a cellular group denominated choanocytes and archaeocyte amoeboids that have several functions, such as obtaining, digesting, and transporting food, besides sexual and asexual reproduction. In the phylum Echinoderms, there is a germ line with late differentiation during embryonic development (Storer and Usinger 1966; Ruppert and Barnes 1996). Thus, changes in the genetic material of somatic cells could be inherited in the next generation under a neoLamarckian model of heredity by natural somatoclonal variation. Somatoclonal selection frequently occurs naturally in angiosperms through rhizomes, tubers, and stems (Hoffmann, 1998). Although we know a great deal about natural cloning, there is still much to learn about vegetative propagation and its evolutionary implications. Due to great advances in genetic engineering and biotechnology, the meaning of genetic changes has been verified with somatoclonal cells and somatic embryogenesis through plant improvement (Ahuja, 1988; Mohan et al., 1988). In addition, this occurs in many primitive phylum of invertebrates, such as porifera, coelenterata, platyhelminthes, nemertinea, and bryozoa, by alternating sexual and asexual reproduction; either by cell dispersion, transversal excision, or budding.

Corresponding author: Daniel Frías L., Instituto de Entomología, Universidad Metropolitana de Ciencias de la Educación Avenida José Pedro Alessandri, 774, Postal code: 7760197, Santiago, Chile, Telephone: 56-2-2412457, Cellular phone: 093331688, Fax number: 56-2-2412728, Email: daniel.frias@umce.cl

Received: January 19, 2010. In revised form: June 24, 2010. Accepted: July 6, 2010. 
New organisms may arise through all these processes (Storer and Usinger, 1966, Ruppert and Barnes, 1996). There is a great regenerative power existing in some of these species, for example the planarian (Turbellarian); any piece of a body may develop into a new entire being (Legner et al., 1976).

In a chapter entitled The Heredity of Acquired Characters of his book The Scientific Basis of Evolution (1943), Thomas H. Morgan stated: "It is not known if the new work in the field of genetics is a mortal blow to the old doctrine of the inheritance of acquired characteristics. The old doctrine held that a modification of the body's cells, produced during development or in adult stages by external agents, is inherited. In other words: a change in the character of the somatic cell determines a change in the germ cells." Morgan then gave arguments to prove the fallacy of the inheritance of acquired characteristics, using stable heritable traits in Drosophila. Undoubtedly, many such arguments are solid and indisputable, but genomic sequencing shows that the genome of many eukaryotic organisms have retrovirus genes that have firstly parasitized somatic cells. According to Steele et al., (1998) the barrier between somatic and germ cells can be sorted through retrovirus and could be responsible for paternal transmission of acquired immunological tolerance.

Horizontal genetic transferences and the importance of viruses in the host's adaptation and organic evolution

In the classic models of population genetics and heredity, small effect mutations are the most important cause of evolutionary novelty by which natural selection acts. With McClintock's discovery of transposable elements in maize, the mechanism of variability became more horizontal. Mobile elements regulate genetic action (Mc Clintock, 1950, 1951) and could also have evolutionary implications through the induction of hybrid dysgenesis and sympatric speciation (Syvanen, 1984). Salvador Luria in 1959 postulated that temperate bacterial viruses might play a role in the evolution of the host (Villarreal, 1999). Stebbins and Ayala (1986) provided new data and a modern reinterpretation in order to expand the Synthetic Theory of Evolution. In that publication these author said: "When new genes arise by duplication, both the original and the duplicated genes have the tendency to be transmitted coupled to the offspring of the organism where the duplication was produced. However, a variant of this process has been discovered that constitutes one of the ways, apparently countless of the evolution at the genetic level. Occasionally, the gene is found in a species and the duplicated gene is present in a distant phylogenetic species. This phenomenon is called horizontal transfer of DNA as it passes from one species to another and co-existing with it. This horizontal genetic transmission is opposed to vertical transmission from parents to children through gametes. The real mechanisms for horizontal gene transfer are unknown. Probably, the vector could be small ring-shaped chains of DNA called plasmid, capable of transporting hereditary material from one cell to another." With the advent of genetic engineering, we now know that plasmids and viruses are vectors in the framework of recombinant DNA technology. The impact of these lateral transferences between bacteria and primitive eukaryotes on organic evolution has been detected in the new tree of life described by Carl R. Woese (1998). According to this new tree, there are three domains: bacteria, archaea, and eukarya. Unique vertical transfer of genes among these domains is not consistent. It was expected that eukarya, with the exception of mitochondria and chloroplast genes, should have only genes from archaea. However, this is not the case, because eukaryotes often have genes from bacterial origin that are not related uniquely to respiration and photosynthesis (Doolittle, 2004).

Horizontal gene transfer has been described in detail in cases of bacterial transformation mediated by viruses (restricted and generalized transduction). Bacteria have obtained a significant proportion of their genetic diversity through the acquisition of sequences from distantly related organisms. These lateral transfers have effectively changed the ecological and pathogenic character of bacterial species (Ochman, et al., 2000, Bardarov, 2002).

The human genome shows evidence that genes were laterally transferred into the genome from prokaryotic organisms. About 40 to 113 genes have been found to be exclusively shared by humans and bacteria and are examples of a direct horizontal transfer from bacteria to the human genome (Salzberg et al., 2001, Villarreal 2001). In addition, many transposable elements in the human genome, such as LINES, SINES (long and short interspersed sequences), are clearly related to endogenous retroviruses (ERV) embedded in the host genome. As well, some DNA polymerases from eukaryotes have a viral origin (Villarreal, 2000, Villarreal 2001). Human chromosome 21 carries 225 protein-encoding genes, but also carries 2000 ERV elements. About $5 \%$ of the human genome contains retroviral and related sequences, similar to proportions exhibited by other species (Prak and Kazazian, 2000; Tristem, 2000), while a lower proportion of human, genome (about $2 \%$ ) contain structural genes.

As part of the host genetic heritage, ERV are transmissible to the next generation in a Mendelian model. Their abundance in animal genomes and their expression in primarily germ cells, embryonic tissue and cancer cell lines raised the question of their biological significance (Prudhomme et al., 2005). The presence of ERV in humans and in the placenta of other mammals has been known for the past 25 years, but the significance of this observation is still not fully understood. It is probably that ancient trophoblastic ERVs had a role in the evolution and divergence of all placental mammals (Harris, 1998).

All mammalian genomes have specific and distinct sets of ERVs and much greater numbers of defective retroviral derivatives, suggesting that mammalian genomes were colonized by specific lineages of ERV soon after placental species radiated from one another. The human genome project indicates that there are thousands of human ERVs that seem to comprise 24 families. Humans have both ancient and newly acquired versions of ERVs, which distinguishes humans from close primate relatives. Mammals are phylogenetically congruent with their ERVs, whereas birds are not. Most mammals express their corresponding ERVs in placental and embryonic tissues. This expression is needed, possibly for immune suppression and other vital developmental processes. ERV forms part of the placental immunosuppressive barrier between mother and fetus, and their expression prevents the rejection of the fetus by the 
maternal immune system. This has solved a major problem of live birth (viviparous) placental mammals. It could also play a role in the origin of adaptive immune systems in animals (Venable et. al, 1995, Villarreal, 1997, 1999, 2001, 2003; Prudhomme, et al. 2005). Therefore, these ERV viruses have a symbiotic relationship with the host.

A similar example of ERV has been described in DNA viruses of parasitic wasps. Mutualistic relationships with polydnavirus have been described in the families Braconidae and Ichneuminidae. The DNA virus is integrated into the parasitoid wasp host genome and seems to be the first documented example of an integrated, nonretroviral DNA virus in insects, and vertically transmitted as a provirus (Fleming, 1991). These viruses are formed only in calyx cells in the ovary of the wasp (Wyler and Lanzrein, 2003). When female wasps implant their eggs into host caterpillar larvae, the viruses are released into the body cavity of a lepidoptera host, suppressing the immune system. This allows the survival of the wasp eggs and larvae to develop into new adults. In this way, polydnavirus in wasps plays a role as a nurse cell by surrounding the eggs and larvae and blocking the caterpillar host's anti-parasite defense response (Villareal, 2001).

These examples in humans and wasps show that not all viral infections are pathogenic. Many viruses can infect their host persistently throughout the host's lifetime without disease. Such viruses can bring the viral seeds of genetic creation into their host (Villareal, 2001, 2003).

Nucleotide sequencing of DNA polyadenvirus has revealed a complex organization, resembling a eukaryote genomic region more than a viral genome. Although endocellular symbiont genomes have undergone a dramatic loss of genes, evolution of symbiotic viruses appears to be characterized by extensive duplication of virulence genes coding for truncated versions of cellular proteins (Espagne et al., 2004).

The importance of heterochromatin, epigenesist, non-coding DNA, and non-transcriptional genes

In the framework of the VIII International Congress of Genetic, in 1949, Richard Goldschmidt finished his oral presentation about " heterochromatic heredity" with the next question: "Should hetrochromatic mutation be considered a major factor in macroevolution?". However, in the synthetic theory of evolution framework, these ideas were not accepted. Evolutionists at that time focused their attention on euchromatic regions where protein coding genes are located. Years later, with the advent of the central dogma of molecular biology, structural genes became even more important in evolutionary genetics. In this conceptual space, the gene was strictly considered as a sequence of nucleotides that resulted from a protein. The rest of the genome was considered "useless genetic material" or "genetic junk".

Heterochromatin, where DNA satellite repeats are located, mediates many diverse functions within the cell nucleus, including centromere functions, gene silencing, and nuclear organization. Recent studies identified methylation of the histone $\mathrm{H} 3$ tail as a post-translational marker that affects acetylation and phosphorylation of histone tail residues, and also acts as a recognition signal for binding of heterochromatin protein 1 (HP1) (Dillon and
Festnstein, 2002). These persistent non-genetic alterations in chromatin have been named epigenetic changes (Dang et al. 2009). The post-translational modification of histone tails generate a "histone code" that defines local and global chromatin states; the resultant regulation of gene function is thought to govern cell fate, proliferation and differentiation (Stral and Allis, 2000). Other epigenetic methylation markers in the histone $3(\mathrm{H} 3)$ in eukaryote $X$ chromosomes have been correlated to active gene expression and also to gene silencing (Lachner et al., 2001, Nakayama et al., 2001). Regulation of X inactivation in mammals is another classic example of epigenetics. The original choice of which $\mathrm{X}$ chromosome will be inactivated occurs early during embryogenesis. Inactivation is random in those cells that form the proper embryo, whereas the paternal $X$ chromosome is always chosen for inactivation in those cells that will form extraembryonic tissues (Park and Kuroda, 2001). This last epigenetic mechanism is an example of a genomic imprinting, similar to those described in sex determination of Coccids (Insecta) (Brown, 1964, 1966).

In recent years, DNA sequencing has revealed that the human genome comprises 3 billion base pairs, but only approximately $2 \%$ correspond to protein coding genes or structural genes. There are other functional genes in this area, such as ribosomal RNA and transfer RNA. The remaining $98 \%$ are non-coding DNA located in heterochromatic areas and repeated DNA. Studies of molecular genetics have shown that these non-coding DNA are useful for the organism and have been called, in a holistic concept, "non-transcriptional genes" (Frías, 2004). Thus, in a broad concept of genes, they correspond to coding or noncoding sequences of DNA that have a role in the body. Therefore, telomeric genes, centromeric genes and origin of replication genes are located in these repeated DNA areas (Frías, 2007a). Recently, non-coding RNA essential in genetic regulation has been discovered and in Pearson's opinion (2006) they could be called "genes". At present we know that many non-coding RNA (small RNA and interference RNA) are important in genetic expression. Many of these doublehelix RNA have a viral origin (Lau and Bartel. 2003).

Prokaryotes and virus have only structural genes that are also present in all eukaryotes. Therefore, these genes can be considered as "precursor genes" or "lower genes" (plesiomophies) of evolutionary processes. Nontranscriptional genes, present only in eukaryotes, are more advanced or higher genes (apomorphies) (Frías, 2007a).

In recent years, studies of speciation have principally focused their attention to DNA sequencing in order to find molecular diagnostic characters at the species level. Molecular phylogenies do not always coincide with morphological phylogenies (Bitsch et al., 2004, Rubinoff and Holland, 2005). Species description is still based on morphology, but molecular tools applied to phylogenetic analysis can be a good complementary approach to infer evolutionary relationships.

\section{The homeotic mutation and the limitation of gradual evolution}

Classically, mutations with small effects have been very important to explain gradualism in organic evolution and biodiversity. Homeotic mutations that regulate the development of eukaryotes were not considered initially in 
the synthetic theory of evolution. Homeosis is a term coined by William Bateson in 1894 in his book Materials for the Study of Variation. Homeotic mutation explains the replacement of a segmental structure by another during development, for example: eye-stalks and antennae (Goldschmidt 1945a). In 1915, Calvin Bridge found the mutation Bithorax in Drosophila. Years later, Goldschmidt described several homeotic mutations in D. melanogaster, particularly those in podoptera, antenna-pedia mutation, tetraltera mutation (transformation of wings into halteres), and tretaptera (transformation of halteres in wings) (Goldschmidt 1945b, 1945c). In his book, The material basis of evolution Goldschmidt proposed a new theory of organic evolution based on these homeotic mutations and introducing the concepts of macroevolution and microevolution (Goldschmidt 1943). Goldschimidt thought that these macromutations explain speciation (macroevolution) by changes in the development of organisms. But this view was not considered by contemporary evolutionists (Dobzhansky, 1940). The cornerstones of the synthetic theory of evolution are microevolution and gradualism, based on mutations with small effects (poligenes). The microevolutionary mechanisms are the same as those that operate at different levels of species and explain the existence of higher taxonomic categories (macroevolution) such as genera, families, orders, class, phylum etc.

But, for Goldschmidt, microevolutionary mechanisms do not explain the formation of species, they only generate polymorphism in populations that are frequently reversible. Homeotic and systemic mutation are fundamental factors on the origin of new species and on other higher taxonomic categories. Many homeotic mutations are not adaptive while others could be. For instance, the mutation of ophthalmoptera described by Morgan in D. melanogaster, which appears as large inflated expansions, usually originating in the eyes, is not an adaptive mutation in Drosophila. Nevertheless, in several species of the genus Phytalmia (Haplostomata, Phytalmiidae) the male is adorned with expanded outgrowths from its eyes, bearing a remarkable resemblance to the more extreme types of ophthalmoptera found in Drosophila. Thus, these homeotic mutations, which are monstrosities in Drosophila, appear as a normal taxonomic feature of the other fly (Goldschmidt and Lederman-Klein, 1959). Many other exaggerated structures have been described in insects, generally seen in males, that are useful for sexual selection (Whittington, 2006; Emlen and Nijhout, 2000).

Currently the works of Garcia-Bellido (1977) and Lewis (1978) on Drosophila homeotic mutations have become fundamental to explain the genetic basis of development and evolution in eukaryote organisms (Carroll, 1995). Homeotic genes are highly conservative and have an important role in the regulation and expression of the gene during the development of eukaryotes. These genes are found in the most primitive invertebrates, vertebrates and plants (Busch et al., 1999 Shenk et at., 1993) and also in the human genome. Major genes are Hox and Pax genes that produce disturbances in early development. The human Hox genes show homology with homeotic box genes of Drosophila. Pax genes contain a nucleotide sequence called paired box, originally described in a segmentation gene in Drosophila (Solari, 1999).
In most taxa, genotypic changes are morphologically manifested to cause evident phenotypic discontinuities in different populations. Based on these discontinuities and fossil evidence, the paleontologists Eldredge and Gould (1972) postulated the theory of punctuated equilibria; an alternative to phyletic gradualism. However, sometimes, morphological changes are minimal, resulting in cryptic species complexes. In these cases, the greatest differences are found in the behavior of individuals. The evolutionary leap is not morphological, but rather behavioral and ecological and the new mechanism of reproductive isolation is premating.

Another aspect that has not received sufficient attention in neo-Darwinism is changes in morphology due to heterochrony and epigenesis during development. Conrad $\mathrm{H}$. Waddington and Richard Goldschmidt warned about this exclusion in a timely manner, but their claims were not considered by other contemporary scientists (Reig, 1991). A few years later, Gould (1977) proposed a model primarily based on development acceleration (hypermorphy) or retardation (neoteny). Both processes cause morphological discontinuities and could give rise to new species (Frías 2009).

Excessive importance to extrinsic barriers in animal speciation

The mode of speciation in natural populations is a central problem in the synthetic theory of evolution. In The Origin of Species Darwin considered speciation as synonymous to evolution and that one species proceeds pre-existing species. Romanes (1897) called speciation the transformation of a species over time and its multiplication in the space (Mayr, 1949). There is consensus that new species arise when new reproductive mechanisms, post-copulatory or precopulatory, appear and suspend the gene flow among populations. However, there is no consensus if these new isolating mechanisms arise in sympatry, allopatry or parapatry. Thus, a problem in speciation is understanding the origin of intrinsic isolating barriers that prevent the gene flow in sympatry. Another task is understanding which evolutionary forces produced these barriers (Coyne and Orr, 2004). The allopatric model is the most widely accepted model of speciation in the framework of the synthetic theory of evolution. Ernest Mayr was the architect this model, in which interest has focused on geographic speciation ( Mayr, 1949, Mayr , 1968). This model is designed as a process of change in a biological system due to external forces. The existence of an extrinsic barrier is a prerequisite to the emergence of new reproductive isolation mechanisms and new species (Mayr, 1949). Therefore, this is a mechanistic model in which animal behavior does not have a role without a prior interruption of gene flow among populations by an extrinsic barrier (Reig, 1991). Considering that several million species have been described and many others have not yet been described, there are not enough geographical barriers to explain the origin of new intrinsic isolation mechanisms and speciation in allopatric conditions. Apparently the allopatric model is not the most parsimonious model to explain speciation. Intrinsic mechanisms of species, such as homeosis, chromosomal rearrangements, development genetics, epigenesis, and behavioral imprinting could be the most common to explain 
the origin of new isolation mechanisms and speciation in sympatry or in semi-geographic conditions.

As an alternative to allopatric speciation, Benjamin Walsh (1864) offered a theory in which a host race of phytophagous insects evolves in sympatry. In The Origin of Species, Darwin emphasized Walsh's idea of the origin of new varieties and species of phytopagous insects in sympatry. Maynard Smith (1966) proposed a theoretical model for sympatric speciation through disruptive selection in a two niche situations. Guy Bush, studying host-race formation in Rhagoletis pomonella (Walsh), has been the main defender of sympatric speciation. It has been shown that the choice of a new host plant can separate populations just as a mountain, an ocean or a river can (Gibbons, 1996; Wu, 1996; Via, 2001, Frías, 2005, Frías, 2007b). Precopulatory reproductive isolation in sympatry has been extensively demonstrated in phytophagous insects, especially in the family Tephritidae of Diptera (Bush, 1969, 1994, Feder et al., 1994, Frías 1989, 2001, 2005). Males and females show host fidelity and their entire life cycle take place on host plants. Host fidelity is mainly due to two classes of odorant: a) characteristic odor released by plants (Christenson and Foote, 1960) and, b) pheromones released by males and females on their host plants (Katsoyannos, 1975; Prokopy, 1976). The olfactory system of insects consists of three classes of proteins: 1) odorant binding protein (OBPs); 2) olfactory receptors (ORs); and 3) odorant degrading enzymes (ODEs). OBPs constitute multi-gene families and consist of two groups: 1) binding proteins of general odorant; and 2) pheromone binding proteins (Sanchez-Gracia, 2005). Changes in chemicals of plants and in proteins of odorant receptors in flies may explain host changes under sympatry.

Most paradigms of sympatric speciation involve colonization by a phytophagous insect of an introduced cultivated host plant (Bush1969, Frías 2007b). Recently however, a model of sympatric speciation has been postulated through the co-evolution between species of the genus Trupanea (Tephritidae) and their host plants of the genus Haplopappus (Asteraceae), based on the hybridization of host plants (Frías, 2005). Compared to other models of sympatric speciation, this is the most parsimonious model of speciation because the hybrid plant is only distributed to places where both parental plants coexist, corresponding to a primary state of the evolution of polyploid complexes in plants, as has been postulated by Stebbins. The new species Trupanea simpatrica is associated with hybrid plants and derived sympatrically from a $T$. foliosis population, which is associated with one of the parental plants (Frías, 2005). Since frequent natural hybridization takes place simpatrically among angiosperm species (Grant, 1981), the model of sympatric speciation in phytophagous insects, involving colonization of newly established hybrid plant species, could be very common in insects associated with Asteraceae ( Frías, 2005).

Recent studies of molecular biology in the nervous system of Drosophila provide a basis for understanding how learned behavior of the larvae could be inherited by the adult. It has been found that some nerve cells of the cephalic ganglion of Drosophila larvae contribute to forming the nervous system of adults. (Gerber and Stocker, 2007). Studies of the parasitoid wasp Aphidium ervi have demonstrated that odor learning during immature stages is transferred to adults, suggesting that the acquisition of an olfactory memory during the larval stage persists through metamorphosis (Gutierrez-Ibañez et al. 2007). These findings indicate that host fidelity could also be determined by behavioral imprinting in the framework of a neo-Lamarckian model.

Although sympatric speciation by hybridization and allopolyploidy in plants is widely accepted, Gallardo et al. (1999) discovered polyploidy in a mammal. This finding gave a window to sympatric speciation in animals in the absence of geographic barriers.

Another model of speciation without geographic barriers, in semi-geographic conditions or parapatric speciation, occurs through intrinsic barriers caused by chromosomal rearrangements and negative heterosis of hybrids (White, 1974;White, 1978; Frías and Atria 1998; Gravilets, 2000). To refer to these karyotypes changes, Goldschmidt introduced the concept of "systemic mutation" based on the transformation of intra-chromosomal pattern. A new spatially different rearrangement of intrachromosomal constitution originates from inversion, translocations, or heterochromatic modifications. And thus a new, stable system emerges that leads to speciation (Goldschmidt 1943; Bush, 1982). Stegnii (1996) extends the concept of systemic mutation incorporating those changes that lead to new rearrangements of the chromocentric apparatus, as well as changes related to the chromosome-membrane connection system.

Goldchmidt's ideas contributed significantly to understanding the role of chromosomal rearrangements in the speciation of certain groups of organisms, especially in Drosophila species (Dobzhansky, 1973; Brncic, 1957). However, the roles of heterochromatic changes and chromocentric apparatus have not been extensively studied. It has been argued that macroevolution has a relationship to centromeric and telomeric heterochromatin changes and also to changes in the chromocentric apparatus for species belonging to two different phyletic groups, Diptera (Tephritidae) and Mepraia (Reduviidae). All these chomosomic rearrangements, especially those in Mepraia spp, explain how postcopulatory reproductive isolation mechanisms, without an extrinsic barrier, originated (Frías and Atria, 1998; Frías, 2009).

\section{CONCLUSION}

It is clear that the genetic code is found in structural genes, lower genes or ancestral genes, which are shared with viruses and prokaryotes. Apparently however, much of the genetic program that makes differentiation and development of a multicellular organisms possible is in non-coding DNA, where non-transcriptional genes, transposable elements and endogenous viruses are located. These genes are linked to the advent of new and vital roles in eukaryotes, such as chromosome origin, mitosis, meiosis, cell differentiation and development. However, the genetic program is not only located in the DNA, but also in higher levels of genomic organization. It has been argued that DNA methylation is a stable epigenetic modification and gene imprinting that evolved independently in angiosperm plants and mammals. (Hsieh et al., 2009; Gehring et al., 2009). Due to genomic imprinting, epigenetic changes are inherited in a different manner from Mendel's principles. 
The genetic code is universal, here we find the basic elements of the genetic program responsible for developing a new organism and new life forms. This program is expressed or terminated due to genetic and epigenetic information and external environmental conditions. Speciation always involves genotypic, epigenotypic and phenotypic leaps. Small leaps originate species, large leaps originate genera, other larger leaps originate families, and thus progressively larger leaps could even explain the emergence of higher systematic categories.

The great extinction of the Jurassic and the great species explosion in the Cambrian and the Cretaceous demonstrate the existence of leaps in the history of organic evolution. These facts indicate that speciation is not gradual. Natural selection does not have a creative effect on species, but rather barriers that the organism must avoid. Intrinsic epigenetic and genetic factors are responsible for inducing the formation of new species in new ecological environments. Neither has atmospheric pressure led to the creation of birds or butterflies, and as Monod and Jacob said, "It is just by chance and necessity." New genomic and epigenomic combinations randomly emerged, and if environments are suitable for these new genotypes, the species are adapted to the environments. Metaphorically speaking, atmospheric pressure did not create the airplane; it is the mechanic who adjusts the vehicle to make it fly.

Moreover, the role of viruses in the evolution and adaptation of prokaryotes and eukaryotes has not been evaluated in the framework of the synthetic theory. There is no bridge between virology and evolutionary theory. This is probably because viruses have long been considered to have originated from the genome of eukaryotes. They would have been fragments of RNA or DNA cells that escaped a long time ago from eukaryotic chromosomes, evolving afterwards by capturing additional genes from the genomes of their hosts. Nevertheless, this view has now been challenged by the discovery of ribozymes and by the surprising homology between viruses with very distantly related hosts, and by phylogenetic analyses suggesting that genes might have flowed from viruses to eukaryotic chromosomes (Fileé et al., 2003).

If RNA viruses were the first living manifestation, then they could be molecular fossils of this primitive RNA world (Chela-Flores, 1994). In this pool, RNA viruses would have evolved first, followed by retro-elements and DNA viruses. The virus world concept and these models of major transitions in the evolution of cells provide complementary pieces of an emerging coherent picture of the history of life (Koonin et al., 2006).

The large amount of retroviruses DNA in the human genome and other eukaryotes, apparently contradicts the debugging role of natural selection. However, the increase in repeated DNA with the complexity of higher organisms shows an adaptive value (Lau and Bartel, 2003). Thus, the paradox of C-value would not be a paradox (Frías, 2007a). A large amount of redundant genetic material in eukaryotes has a viral origin, in particular small RNA, RNA interference, introns and mobile genetic elements. All these genetics elements were horizontally acquired, but once incorporated into the host genome and passing the Weissman barrier, they were vertically transmitted according a Mendelian model of heredity. Thus, Steele's assumption is probably correct and his model could be expanded to explain the heredity of the large amount of DNA retrovirus in eukaryotes. It has been have been found that DNA virus (polydnvirus) in parasitic wasps could be embedded in the genome of the host. Both DNA viruses and retroviruses have a symbiotic relationship with the host.

Findings in the human genome, such as genes from bacteria, viruses acquired by horizontal transmission and homologous regions of human genes with other organisms, such as Drosophila (Katoh and Katoh, 2003), indicate that the eukaryotic genome is unstable over a long time-scale. However, it may be a mosaic flow of information from different sources in a symbiotic co-evolutionary process. The study of the human genome evolution has concentrated on humans and their hominid ancestors, without much attention to other organisms and viruses that also evolved from the same environments (Van Blerkom, 2003).

With respect to genes of endogenous viruses embedded in the host genome, there is doubt whether these genes should be considered foreign or from the host, as occurs with mitochondrial and chloroplast genes. It is necessary to establish bridges between viruses and eukaryotic genome organization to better understanding the role of lateral genetic transferences in macro-evolutionary processes. In particular, it is necessary to carry out functional genomics studies.

Through the contributions of Lynn Margulis (1988), it is currently accepted that mitochondria and chloroplast are endosymbionts of bacterial origin. Many biologists also accept the ecological Gaia hypothesis of Lovelock and Margulis (1974), where living organism are integrated with other physical components in our planet in order to maintain a dynamic balance or homeostasis in the system that counteracts the second law of thermodynamics. It is likely that viruses have participated for millions of years as "workers", remodeling the eukaryotic genome and producing evolutionary novelties together with other classical mechanisms, such as homeotic and systemic mutations and chromosomic rearrangements, joined to other factors like epigenesis and heterochrony during development. All these new molecular aspects uncovered by the synthetic theory of evolution suggest the need to make a new evolutionary synthesis.

\section{ACKNOWLEDGEMENTS}

This is a posthumous tribute to Dr. Gustavo Hoecker Salas

Thank to an anonymous reviewer for his suggestions that helped me improve the manuscript. This research has been supported by Project FIBAS 06/ 08 DIUMCE.

\section{REFERENCES}

AHUJA MR (1988) Somatic Cell Genetics of Woody Plants. Luwer Academic Publishers. USA.231 pp.

BARDAROV S, BARDAROV JR M S, PAVELKA V, SAMBANDAMURTHY M, LARSEN J, TUFARIELLO J, CHAN G HATFULL, JACOBS W R (2002) Specialized transduction: an efficient method for generating marked and unmarked targeted gene disruptions in Mycobacterium tuberculosis, M. bovis BCG and $M$. smegmatis. Microbiology 148: 3007-3017.

BITSCH J, BITSCH C, BOURGOIN TH, HAENSE CD (2004) The phylogenetic position of early hexapod lineages: morphological data contradict molecular data. Syst Entomol 29:433-440. 
BRNCIC D (1957) Heterosis and the integration of the genotype in geographic populations of Drosophila pseudoobscura. Genetics 39: 7788.

BROWN SW (1964) Heterochromatic chromosomes in the Coccids. Science 145 (3628): 130-136.

BROWN SW (1966) Heterochromatin. Science 28 (151): 417-425.

BUSCH MA, BOMBLIES K, WEIGEL D (1999) Activation of a floral homeotic gene in Arabidopsis. Science 285 (5427): 585-587.

BUSH GL (1969). Mating behaviour, host specificity, and ecological significance of sibling species in frugivorous flies of the genus Rhagoletis (Diptera: Tephritidae). Am Nat 103 (934): 669-672).

BUSH GL (1982). Goldschmidt's Folies. Paleobiology, 8 (4): 463-469.

BUSH GL (1994). Sympatric speciation: new wine in old bottles. Trends Ecology Evol 9: 285-288.

CARROLL SB (1995) Homeotic genes and the evolution of Arthropods and Chordates. Nature 376: 479-485.

CECH TR (1986) RNA as an enzyme. Scientific American 253: 51-59.

CHELA-FLORES J (1994) Are viroids molecular fossils of the RNA world? J Th Biol 166: 163-166.

COYNE JA, ORR HA ( 2004) Species: Reality and Concepts: 9-54. In Coyne JA, ORR HA ed, Speciation, Sinauer Associates,Inc.Publisher, Sunderland Massachusets USA:545 pp.

CHRISTENSON LD, FOOTE RH (1960) Biology of fruit flies. Ann Rev Entomol 5: 171-192.

DANG W K, STEFFEN $K$, PERRY R, DORSEY JA, JOHNSON FB, SHILATIFARD A, KAEBERLEIN M, KENNEDY BK, BERGER SL (2009) Histone H4 lysine 16 acetylation regulate cellular lifespan. Nature 459 ( 7248): 802-807.

DARLINGTON CD (1937) The early hibridisers and the origins of Genetics. Herbetia: 63-69

DARWIN CH (1983) El Orígen de las Especies. Sarpe, Madrid. 638 pag.

DILLON N, FESTENSTEIN R (2002) Unravelling heterochromatin: competition between positive and negative factors regulates accessibility. Trends Genet 18 (5): 252-258.

DOBZHANSKY TH (1940) Catastrophism versus evolutionism. Science 2390: 356-358.

DOBZHANSKY TH (1973) Genetica do Processo Evolutivo. Editora da Universidade de São Paulo. Brasil, 453 pp.

DOOLITTLE WF (2004) Nuevo árbol de la vida. En: Temas 35, Biodiversidad. Investigación y Ciencias, Primer Semestre 2004. Prensa Científica, S.A. España: 12-17 pp.

EAST EM (1924) Two decades of genetic progress. Annual Report Smithsonian Institution, Washington Government Printing Office, 2734: $285-295$

ELDREDGE N, GOULD S J (1972) Punctuated equilibria: an alternative to phyletic gradualism In T.J.M. Schopf,(ed)., Models in Paleobiology. San Francisco: Freeman Cooper. pp. 82-115.

EMLEN DJ NIJHOUT HF (2000) The development and evolution of exaggerated morphologies in insects. Ann Rev Entomol 45: 661-708.

ESPAGNE E, DUPUY C, HUGUET E, CATTOLICO L, PROVOST B, MARTINS N, POIRIÉ M, PERIQUET G, DREZEN JM (2004) Genome Sequence of a Polydnavirus: Insights into Symbiotic Virus Evolution. Science 306 (5694): 286-289.

FEDER LJ, OPP SB, WLAZLO B, REYNOLD K, GO W, SPISAK S (1994) Host fidelity is an effective premating barrier between sympatric races of the apple maggot fly. Proceedings of Natl Acad Sci 91: 117135.

FLEMING JG, SUMMERS MD (1991) Polydnavirus DNA is integrated in the DNA of its parasitoid wasp host. Proc Natl Acad Sci 88 ( 21) 97709774.

FILÉE J, FORTERRE P, LAUREN J (2003) The role played by viruses in the evolution of their hosts: a view based on informational protein phylogenies. Res Microbiol 154 (4): 237-243.

FRÍAS LD (1989) Diferenciación ecológica y reproductiva de dos razas huéspedes de Rhagoletis conversa (Bréthes) (Diptera: Tephritidae). Act Entomol Chil 15: 163-170. FRÍAS LD ATRIA J (1998) Chromosomal variation, macroevolution and possible parapatric speciation in Mepraia spinolai (Porter) (Hemiptera: Rediviidae). Gen Mol Biol 21 (2):179-184

FRÍAS LD (2001) Diferencias genéticas y morfológicas de los estados inmaduros de dos razas de Rhagoletis conversa (Bréthes) ( Diptera: Tephritidae) asociadas a plantas Solanum, distribución geográfica y posible orígen en simpatría de una nueva especie. Rev Chil Hist Nat 74: 73-90.

FRÍAS LD (2004) La hetrocromatina y su rol functional. ¿Qué es un gen?,
Desde el dogma central de la biología molecular a la secuenciación del genoma humano. RIL Editores, $148 \mathrm{pp}$.

FRÍAS LD (2005) Trupanea simpatrica a new species of Tephritinae (Diptera:Tephritidae) infesting an endemic Haplopappus hybrid ( Asteraceae) in Chile. Act Entomol Chil 29 (1):13-45.

FRÍAS LD (2007)a The phylogeny of the gene, fom " Lower" naked structural genes to "Higher" Non-Transcriptional Genes. Riv Biol/ Biol For 100: 221-246.

FRÍAS LD ( 2007)b Especiación simpátrica y sus implicaciones genéticas y morfológicas en moscas de la fruta. En: HERNÁNDEZ-ORTIZ (ed) Moscas de las frutas en Latinoamérica (Diptera: Tephritidae): Diversidad, Biología y Manejo. S y G. editores, Distrito Federal, México. pp 1-26.

FRÍAS LD (2009) Genetics and epigenetics variation in the sex chromosomes and their impact on morphological changes and parapatric speciation: species of the genus Mepraia in Chile ( Hemiptera:Reduviidae) a case study. In: ) WEINGARTEN CN, JEFFERSON SE (eds) Sex chromosomes : Genetics, abnormalities, and disorders. Nova Science Publishers,Inc. pp.165-206.

GALLARDO MH, BICKHAM JW, HONEYCUTT RL, OJEDA RA, KÖHLER N (1999). Discovery of Tetraploidy in Mammal. Nature 401: 341.

GARCÍA-BELLIDO A (1977) Homeotic and atavic mutations in insects. Am Zool 1: 613-629.

GEHRING M, BUBB KL, HENIKOFF S (2009) Extensive demethylation of repetitive elements during seed development underlies gene imprinting. Science 324: 1447-1451. GERBER B STOCKER RF (2007) The Drosophila larva as a model for studing chemosensation and chemosensory learning: A review. Chem Sen 32: 65-89.

GIBBONS A. (1996) On the many origins of species. Science 173: 14961499.

GOLDSCHMIDT B (1943) La base material de la evolución. Espasa-Calpe, Buenos Aires, Argentina S.A, 364 pp.

GOLDSCHMIDT RB (1945)a The structure of podoptera, a homotic mutant of Drosophila melanogaster. J Morphol 77 (1): 71-103.

GOLDSCHMIDT RB (1945)b Podoptera, a homeotic mutant of Drosophila and the origin of insects wings. Science 101 (2624): 389-390.

GOLDSCHMIDT RB (1945)c. Evolution of mouth parts in diptera a counter critique. Pan-Pacif Entomol 21: 41-47.

GOLDSCHMIDT RB (1949) Heterochromatic Heredity. Reprinted from Proceedings of the Eigth International Congress of Genetics. Hereditas Suppl Vol: 244-255.

GOLDSCHMIDT E, LEDERMAN-KLEIN A (1959) Reocurrence of a forgotten homeotic mutant in Drosophila. J Hered XLIX (6): 262-266.

GOULD SJ (1977) Ontogeny and phylogeny. The Belknap Press of Harvard Universitty Press, Cambridge, Massachusetts London, England 501 pag.

GRANT V (1981) Plants speciation. Columbia University Press, New York, $563 \mathrm{pp}$

GRAVILETS S ( 2000) Waiting time to parapatric speciation. Proc. Roy.Soc. Lon. 267: 2183-2192.

GUTIÉRREZ-IBAÑEZ CH, VILLAGRA CH A, NIEMEYER HM (2007) Prepupation behaviour of the aphid parasitoid Aphidius ervi (Haliday) and its consequences for preimaginal learning. Naturwissenschaften DOI 10.1007/s001 14-007-0233-3 . Springer Verlag

HARRIS J R (1998) Placental endogenous retrovirus ( ERV) : structural functional and evolutionary significance. BioEssays 20.4: 307-316.

HSIEH TF, IBARRA CHA, SILVA PO, ZEMACH A, ESHED-WILLIAMSL, FISCHER RL, ZILBERMAN D (2009) Genome-wide demethylation of Arabidopsis endosperm. Science 324: 1451-1454.

HOFFMANN WA (1998) Post-burn reproduction of woody plants in Neotropical Savanna: the relative importance of sexual and vegetative reproduction. J appl Ecol 35: 422-433.

KATOH M, KATOH M (2003) Comparative genomics between Drosophila and human. Gen Inform 14: 587-588.

KATSOYANNOS BI (1975) Ovipositing-deterring, male-arresting,fruitmarking pheromone in Rhagoloetis cerasi (Diptera Tephritidae) Environ Entomol 4(5): 801-805

KOONIN E, SENKEVICH VTG, DOLJA VV (2006) The ancient Virus World and evolution of cells. Biol Dir 5: 1-29.

LACHNER M, OCARROLL DM, REA S, MECHTLER K, JENUWEIN T (2001) Methylation of Histone H3 Lysine 9 creates a binding site for HP1 proteins . Nature 410: 116-120.

LAU NC, BARTEL DP (2003) Interferencia de ARN. Investigación y Ciencias, Octubre 2003: 6-13. 
LEGNER EF, TSAI TC, MEDVED RA (1976) Environmental stimulants to asexual reproduction in the planarian, Dugesia dorotocephala. Entomophaga 21(4): 415-423.

LEWIS EB (1978) A gene complex controlling segmentation in Drosophila. Nature 276: 565-570

LOVELOCK JE, MARGULIS L (1974) “Atmospheric homeostasis by and for the biosphere- The Gaia hypothesis". Tellus 26 (1): 2-10.

MARGULIS L (1988) El orígen de la Célula. Editorial Reverte, S.A. Barcelona, $150 \mathrm{pp}$.

MAYNARD SMITH J ( 1966) Sympatic speciation. Am. Nat. 100: 637650

MAYR E (1949) Speciation and systematics. In: JEPSEN GS, SIMPSON GC MAYR E (eds) Genetics, paleontology and evolution. Princeton University Press. Pp 281-298.

MAYR E ( 1968) Especies animales y evolución. Ediciones de la Universidad de Chile. Ediciones Ariel S.A.808 pp.

MCCLINTOCK B (1950) "The origin and behavior of mutable loci in maize". Proceedings of the Natl Acad Sci. 36: 344-555

MCCLINTOCK B (1951) Mutable loci in maize. Carnegie Institution of Washington Yearbook 50, 174-181

MOHAN J S, NEWTON RJ, SOLTEN EJ (1988) Enhancement of somatic embryogenesis in Norway Spruce ( Picea abies L.) Theor Appl Gen 76 501-506.

MORGAN TH (1943) La Base Científica de la Evolución. Espasa-Calpes S.A., Buenos Aires, Argentina, 329 pp.

NAKAYAMA J, RICE JC, STRAHL BD, ALLIS CD, GREWAL SI (2001) Role of histone H3 Lysine 9 methylation in epigenetic control of heterochromatin assembly. Science 292: 110-113.

OCHMAN H, LAWRENCE JG GROISMAN EA (2000) Lateral gene transfer and the nature of bacterial innovation. Nature 405: 299-304.

PEARSON H (2006) What is a gene?. Nature 44:399-401.

PRAK ET, KAZAZIAN HH JR (2000). Mobile elements and the human genome. Nature Rev Genet. 1, 134-144.

PARK Y, MI KURODA (2001) Epigenetic aspects of X- chromosome dosage compensation. Science 293: 1083-1085.

PRUDHOMME S, BONNAUD B, MALLET F (2005) Endogenous retroviruses and animal reproduction. Cyt Gen Res 2005;110:353-364.

PROKOPY RJ (1976) Feeding, mating and oviposition activities of Rhagoletis fausta flies in nature. Ann Entomol Soc Am 69: 899-904.

REIG OA (1991) El desafío de la genética del ADN recombinante y de la biología del desarrollo para la Teoría Sintética de la Evolución. Arch Biol Med Exp 24: 425-436. RUBINOFF D, HOLLAND BS (2005) Between two extremes: mitochondrial DNA is neither the panacea nor the nemesis of phylogenetic and taxonomic inference. Syst Biol 54( 6) 952-961.

RUPPERT EE, BARNES RD (1996) Zoología de los invertebrados. McGraw-Hill. Interamericana Ediciones S.A. México 1114 pp.

SALZBERG, SL, WHITE O, PETERSON J, EISEN JA (2001) Microbial Genes in the Human Genome: Lateral Transfer or Gene Loss? Science 8: Vol. 292 ( 5523): 1903-1906

SANCHEZ-GRACIA A (2005) Evolución molecular de los genes OS-E y OS-F en diferentes especies de Drosophila . Universidad de Barcelona Facultad de Biología, Departamento de Genética. Barcelona,24 pp.

SHENK MA, BODE HR, STEELE RE (1993) Expression of Cnox-2, a Hom Hox homeobox gene in hydra, is correlated with axial pattern formation. Development 117: 657-667.

SOLARI AJ (1999) Genetica Humana. Fundamentos y aplicaciones en Medicina. Editorial Médica Panamericana, Buenos Aires, 370 pp.
STEBBINS GL, AYALA F (1985) La evolución del darwinismo.Invest Cien 108: $42-53$

STEELE EJ, LINDLEY RA, BLANDEN RV (1998) Lamarck's signature. Allen and Unwin, Sydney, Australia, $286 \mathrm{pp}$.

STEGNII VN (1996) The problem of systemic mutations. Russ J Gen 32 (1): $14-22$

STORER TL, USINGER RL (1966) Zoología General. 2a edición, Barcelona, Editorial Omega. 1003 pp.

STRAHL BD, ALLIS CD (2000) The language of covalent histone modifications. Nature 403: 41-45.

SYVANEN M (1984) The evolutionary implications of mobile genetic elements. Ann Rev Gen. 18: 271-293.

TRISTEM M (2000) Identification and characterization of novel human endogenous retrovirus families by phylogenetic screening of the human genome mapping project database. J Virol 74, 3715-3730.

VAN BLERKOM LM (2003) Role of viruses in human evolution. Yearbook Phys Anthropol 46:14-46.

VENABLES,P J, BROOKES S M, GRIFFITHS D, WEISS R A, BOYD M T (1995) Abundance of an endogenous retroviral envelope protein in placental trophoblasts suggests a biological function. Virology 211, 589-592, doi:10.1006/viro.1995.1442.

VERGARA FS (2002) La homeosis y la macroevolución. Ciencia 065: $42-$ 50. Red de Revistas Cientificas de América Latina y el Caribe, España y Portugal. Universidad Autónoma de México.

VIA S (2001) Sympatric speciation in animals: the ugly duckling grown up. Trends Ecol. Evol. 16: 381-390.

VILLARREAL LP (1997) On viruses, sex, and motherhood. J Virol February: 859-865.

VILLARREAL LP (1999) DNA virus contribution to host evolution : 391420. In: DOMINGO E, WEBSTER R HOLLABD J (EDS) Origin and Evolution of viruses. Academic Press, New York.

VILLARREAL LP (2000) A hypothesis for DNA viruses as the origin of eukaryotic réplication proteins. J Virol 74 (15): 7079-7084

VILLARREAL LP (2001) Persisting viruses coul play role in driving host evolution. Am Soc Adv Sci News. 67 (10): 501-507.

VILLARREAL LP (2003) Can viruses make us human? Proc Am Phil Soc 148 (3): 296-323.

WALSH DB (1864) On phytophagic varities and phytophagous species. Proc Entomol Soc Phil III: 403-430.

WHITE MJD (1974) Speciation in the Australian morabine grasshoppers. The cytogenetic evidence. In WHITE MJD (ed) Genetic Mechanisms of Speciation in Insects. Australian and New Zealand Book, Sidney, Pp 57-58

WHITE MJD (1978) Modes of Speciation. DAVERN CI (ed). WH Freeman and Company, San Francisco, USA. PAGS???

WITTINGTON AE (2006) Extreme head morphology in plastotephritinae (Diptera: Platystomatidae), with a propoition of classification of head structures in Acalyptratae Diptera: 61-83. In: MERZ B (ED) Phylogeny, Taxonomy and Biology of Tephritoid flies (Diptera: Tephritidae). Museum d'Histoire Naturelle, Geneve, Switzerland, 274 $\mathrm{pp}$

WOESE CR (1998) The universal ancestors.Proceedings of the Natl Acad Sci 95 (12): 6854-6859.

WYLER T, LANZREIN B (2003) Ovary development and polydnavirus morphogenesis in the parasitic wasp Chelonus inanitus. II. Ultrastructural analysis of calyx cell development, virion formation and release. J Gen Virol 84: 1151-1163.

WU CL (1996) Endless forms,several powers. Nature 382: 298-299. 